\title{
Development of community based curriculum on ophthalmology for under graduate medical course in Bangladesh
}

\author{
Khan $\mathrm{AK}^{1}$, Hussain AZMI ${ }^{2}$ \\ ${ }^{1}$ Depertment of Ophthalmology, Gonosayastha Somaj Vittik Medical College, Savar \& Dhanmondi, \\ Dhaka. ${ }^{2}$ UniSA School of Public Health and Life Sciences, University of South Asia, Banani, Dhaka. \\ Email:dristisheba@hotmail.com
}

\begin{abstract}
The curriculum represents the expression of educational ideas in practice. Ophthalmic education is the corner stone to improve eye care globally. Curriculum needs continuous modification varying in different geographic locations. Though $90 \%$ of common conditions are either preventable or curable but emphasis on the common conditions is inadequate. This is a stepwise descriptive study aiming to develop a community based ophthalmology curriculum for undergraduate medical course in Bangladesh conducted during March 2007 to February 2008 at UniSA School of Public Health and Life Sciences, University of South Asia, Banani, Dhaka. Delphi technique, a modified qualitative method was used to accumulate data and reaching a consensus opinion for developing the curriculum. Study approach includes two iterative rounds and finally a workshop. Iteration of round-I was "What are the eye diseases with overall knowledge of their management one MBBS physician should acquire"; followed by a list of eye diseases and topics for expert opinion. The response was collated. Iteration round-II was "How much a MBBS student should have percentage of knowledge, attitude and skills on each topic while being taught". The response was collated and presented to panel of expert ophthalmologists for discussion and validation. In the round-I Delphi, 400 (62\%) out to total 641 ophthalmologist were randomly selected dividing in categories (62\% in each) of Professor-22, Associate Professor-12, Assistant Professor-26, Consultant-27, ophthalmologists working in NGO-56 and ophthalmologists in private sector-257. Sixty (15\%) responded with opinion. In the round-II, 200 (31\%) including 60 of round-I, selected randomly but proportionately as before. Forty five $(22.5 \%)$ responded with opinion. Result collated. The results and opinion of respondents were presented at a workshop attended by 24(80\%), out of 30 invited expert ophthalmic specialists for discussion, criticism, opinion, addition, modification and finally for validation. On the basis of the opinion of the respondents, reviewing literature, analyzing the ocular disease pattern in Bangladesh and also analyzing the present ophthalmology curriculum, a community and need based ophthalmology curriculum for undergraduate medical course in Bangladesh was developed. This research would help developing community and need based ophthalmology curriculum for undergraduate medical course in Bangladesh.
\end{abstract}

\section{Introduction}

The curriculum represents the expression of educational ideas in practice. It includes all the planned learning experiences of a school or educational institution. Curriculum development is a continuous process and always open for critique ${ }^{1}$.

Ophthalmic education is the cornerstone to improve eye care globally. Expert realizes the wide variability of educational standards, pattern and prevalence of diseases, social structures for provision of eye care in geographical regions. Therefore encourages continuous modification of curriculum according to the needs of different global communities ${ }^{2}$.

A curriculum should have room range for making it fit to prepare student for better future career opportunities and equip them efficient enough to meet the community need and demand. Curriculum should reflect society's need and should contribute in making shift the society for fulfilling the needs ${ }^{3}$.

Curriculum development should be a conjoint effort of all stake holders including the community, educational institute and recipient organization, who will be using the successful students in future. Developing curriculum in isolation will merely a guideline for teachers but those who will be taught will not be able to meet the need of the service providers 4 .

The purpose of the curriculum is to bring order, coherence and intellectual discipline to the transmission of stored human experiences $\mathbf{5}$. 
The curriculum exists at three levels: what is planned for the students, what is delivered to the students, and what is the student's experience.

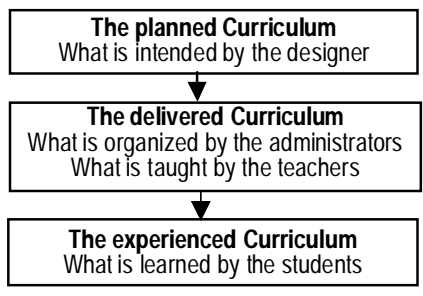

Figure-1: Three levels of a curriculum

In contemporary medical education it is argued that the curriculum should achieve a "symbiosis" with the health services and communities in which the students will serve. The values that underlie the curriculum should enhance health service provision. The curriculum must be responsive to changing values and expectations in education if it needs to remain useful.

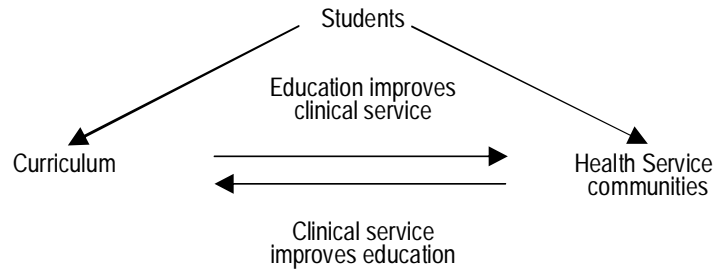

Figure-2: "Symbiosis" necessary for a curriculum ${ }^{6}$

Bangladesh, a thickly populated country over 160 million inhabitants of which $72 \%$ are rural, farming is main occupation, $40 \%$ live below national poverty level and $44 \%$ are illiterate ${ }^{7}$. Rural people are poor, illiterate and under privileged and they are backbone of agro-based economy of Bangladesh and produce food for us.

There are approximately 626 Ophthalmologists in Bangladesh, $45 \%$ resides in Dhaka city alone ${ }^{8}, 1$ to 3 at district level and virtually none at upazilla level for 3.5 lac population. Whereas WHO recommends one for 50,000 in developing countries ${ }^{9}$.

There are approximately 675,000 blinds in the country, $75-80 \%$ of which is avoidable, either preventable or curable. Main causes of low vision are cataract $74 \%$ refractive error $18.7 \%$, corneal deceases, retinal diseases, glaucoma, optic nerve diseases, diabetic retinopathy and so on ${ }^{\mathbf{1 0}}$. There are about 40,000 blind children in Bangladesh ${ }^{8}$.

The Government of Bangladesh has identified blindness as a critical and social health problem and has ratified the WHO program 'Vision 2020-The Right to Sight'. The national eye care plan is adopted for Bangladesh ${ }^{8}$.

The right to sight is equal for urban and rural people but reality is there is virtually no Ophthalmologist for rural $72 \%$ people. Last $10-15$ years trend of producing Ophthalmologists and their distribution nationwide predicts least possibility of improvement by next 15-20 years. At this situation graduate physician working in rural area has great role to play at least to give primary eye care for unreached people.

General physicians' (GP) view their undergraduate ophthalmic medical education as inadequate and is reflected in their confidence and understanding ${ }^{11}$.

Inadequate clinical exposure and lecture at the undergraduate level is important reason why many GP do not treat the eye conditions but refer them to eye specialist ${ }^{\mathbf{2}}$.

Medical education in South East Asia Region (SEAR) follows legacy of colonial past and perceived to be divorced from the real needs of the people ${ }^{13}$, also true for ophthalmology. Ninety percent common eye conditions are avoidable but emphasis on Primary Eye Care (PEC) is inadequate. However undergraduate students are not adequately exposed to primary eye care, which is essential for proper eye care in all countries of the South East Asia Region ${ }^{12}$.

In Bangladesh ophthalmology training is a part of surgery and evaluation is done with surgery during professional examination ${ }^{14}$.

WHO recommends that, the curriculum for ophthalmology at undergraduate level needs to be reconstructed urgently, community eye care needs more attention, community oriented and community based teaching should be an integrated part of curricula, community ophthalmology should have designated teaching hours, training of faculty and faculty student ratio should draw attention \& prioritization of learning topics should be done ${ }^{\mathbf{1 2}}$.

Curriculum is product of consensus of all concerned. Through community need based development of ophthalmology curriculum and it's implementation maintaining a standard throughout nation to improve capability of graduate physicians during undergraduate education can ensure PEC and fulfill the obligation to serve unreached rural people to address the success of Vision-2020, The Right to Sight.

Current curriculum ${ }^{14}$ determines a list of content rather than a total community need based curriculum, is effective as such for the last 8 years since 2002 without any enrichment. It could not adequately equipped enough the medical graduates with knowledge, attitude and skill to meet the community health needs. This is high time for modification to make it an effective training tool, to prepare efficient medical graduates to address the growing local eye care needs and for fulfillment of global commitment of elimination of avoidable blindness.

The objective of the study was to develop a community based curriculum on ophthalmology for undergraduate medical course in Bangladesh. 


\section{Materials and Methods}

This is a step wise descriptive study conducted from March 2007 to February 2008 at UniSA school of Public Health and life Sciences, University of South Asia, Dhaka, Bangladesh. Ophthalmologists, members of the Ophthalmological Society of Bangladesh, all around nation were the study population.

Research Technique: The Delphi technique, a modified qualitative method was used to accumulate data and reaching a consensus opinion for developing the curriculum. The technique is seen as a procedure to "obtain the most reliable consensus of opinion of a group of experts, by a series of intensive questionnaires interspersed with controlled opinion feedback" ${ }^{, 15}$.

Four key features may be regarded as necessary for defining a procedure as a 'Delphi'. These are: anonymity, iteration, controlled feedback and the statistical aggregation of group response. The original Delphi method used experts panel members ${ }^{15}$. In this study an attempt was made to select a sample of broadly representative ophthalmologists who within the term of this study represent a panel of informed experts by reason of their day to day involvement with eye patients in urban, sub-urban and rural areas dispersed throughout Bangladesh.

Study approach includes two iterative rounds, validation workshop and finally development of new curriculum.

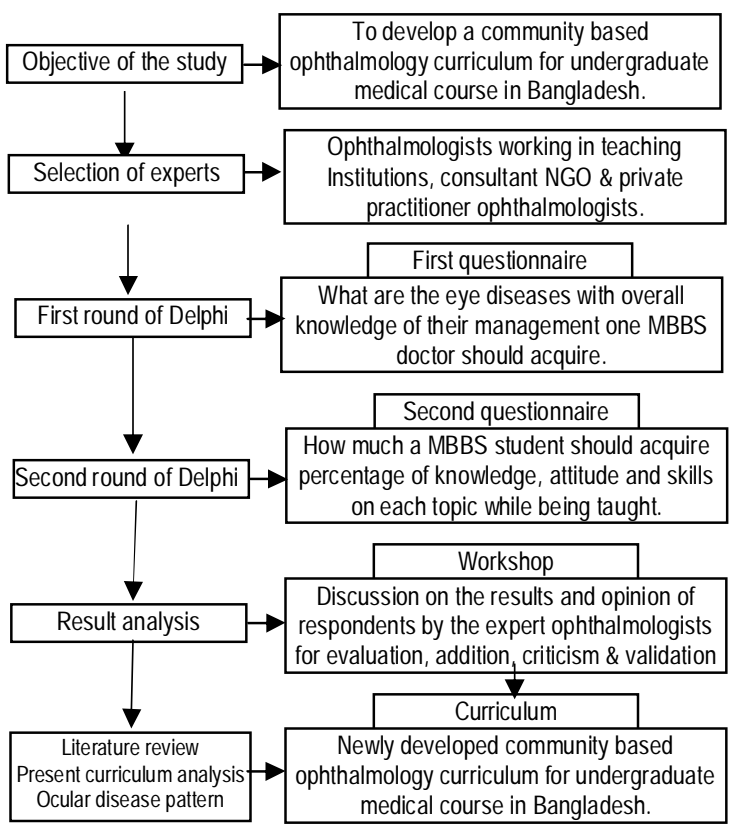

Figure-3: Flow Chart of Methodology

Research Instrument

Round-I

A pretested questionnaire used in the first iteration which was designed as part of the largest study. The question was "What are the eye diseases with overall knowledge of their management one MBBS doctor should have?" The iteration was followed with a list of eye diseases, essential eye equipments, examination procedure required for diagnosis for opinion with a room to add new topics.

\section{Round-II}

Responds to first questionnaire was collated and the subject/ topics in each group rearranged according to the priority of importance and necessity from above bellow on the basis of the opinion of the respondent. Additional 33 topics proposed by the respondents were included in the list.

The second questionnaire than developed, pre testing done and the question was "How much a MBBS student should acquire percentage of knowledge, attitude and skill on each subjects while being taught?" The list of the subjects/topics followed the question. In this round respondents requested to mark for knowledge, attitude and skill out of 100, according to importance considering each topic individually. Explanation with an example added how to respond in this iteration. These ratings were collated. Mean of knowledge, attitude and skills for each topic calculated.

Validation workshop: A workshop was organized chaired by the most senior ophthalmic scientists of Bangladesh, for discussion, question and answering, opinion, criticism, evaluation, addition, change or modification and finally validation.

\section{Result}

In the round-I Delphi, 400 (62\%) out to total 641 ophthalmologist were randomly selected dividing in categories (62\% in each) of Professor, Associate Professor, Assistant Professor, Consultant, ophthalmologist working in NGO and Private ophthalmologists. Sixty (15\%) responded with opinion in round -I.

Table -I: Distribution of participants in Delphi round-1

\begin{tabular}{lcccc}
\hline $\begin{array}{c}\text { Category of } \\
\text { ophthalmologist }\end{array}$ & $\begin{array}{c}\text { Total Number } \\
\text { of } \\
\text { Ophthalmology }\end{array}$ & $\begin{array}{c}\text { Selected } \\
\text { for sample }\end{array}$ & $\begin{array}{c}\text { Percentage } \\
\text { out of } \\
\mathrm{n}=641\end{array}$ & $\begin{array}{c}\text { Selected } \\
\text { participants \% } \\
\text { out of } \mathrm{n}=400\end{array}$ \\
\hline Professor & 35 & 22 & 62 & 5.5 \\
Asso. Prof. & 19 & 12 & 62 & 3 \\
Asstt Prof. & 42 & 26 & 62 & 6.5 \\
RS. Registrar & & & & \\
Consultant & 40 & 27 & 62 & 7 \\
NGO & 91 & 56 & 62 & 14 \\
Private & 414 & 257 & 62 & 64 \\
Total & 641 & 400 & 62 & 100 \\
\hline
\end{tabular}

In the round-II $200 \quad(31 \%)$ ophthalmologists including 60 of round-I, selected randomly but proportionately as before and $45(22.5 \%)$ responded. Result collated and finally presented at workshop participated by randomly selected panel of $24(80 \%)$ out of invited 30 expert ophthalmologists for discussion and validation. 


\section{Result and analysis of round $-I$}

As a part of Delphi technique Round-1 questionnaire was mailed to the respondents for opinion against the question "What are the eye diseases with overall knowledge of their management one MBBS doctor should acquire?"

A list of topics were given arranged around different concentrate like orbit, lid and so on. Topics were chosen by putting tick $(\checkmark)$ in box marked with "agreed" or "disagreed".

Respondents opinion were calculated in terms of number and percentage showed against each topic.

Table-II:Respondents opinion in terms of number \& \%, an example:

\begin{tabular}{lcc}
\hline $\begin{array}{c}\text { Topic Concentrate } \\
\text { LIDS }\end{array}$ & $\begin{array}{c}\text { Agreed respondents } \\
\mathrm{n}=60\end{array}$ & $\begin{array}{c}\% \text { agreed } \\
\text { respondents }\end{array}$ \\
\hline Stye & 60 & 100 \\
Chalazion & 60 & 100 \\
Blepharitis & 51 & 85 \\
Trichiasis & 45 & 75 \\
Ptosis & 43 & 71.6 \\
Ectropion & 37 & 61.6 \\
Entropion & 36 & 60 \\
\hline
\end{tabular}

Table-III: Topics arranged according to the priority based on the analyses of the all precious topics of round-I.

91-100\% Stye, chalazion, viral conjunctivitis, allergic conjunctivitis, bacterial conjunctivitis, bacterial corneal ulcer, acute dacryocystitis, xerophthalmia, tourch, snellen's chart.

81-90\% Orbital cellulitis, blepharitis, vernal conjunctivitis, ptrygium, sac abscess, chronic dacryocystitis, congenital cataract, age related cataract, primary agnle closure glaucoma, Keratomalacia, corneal abrassion,

$71-80 \%$ Trichiasis, ectropion, ptosis, congenital NLD obostruc-tion, fungal corneal ulcer, presbiopia, lid injury, corneal injury, chemical burn, near vision testing chart.

61-70\% Episcleritis, acute iritis, congenital glaucoma, primary open angle glaucoma, diabetic retinopathy, thermal burn, sub tarsal foreign body, squint, direct ophthalmoscope, Flu dye test, sac patency test.

51-60\% Herpes simplex viral keratitis, hypertensive retinopathy, hypermetropia, myopia, dermoid, retinoblastoma, leucocoria, ophthalmoscopy.

41-50\% Thyroid ophthalmopathy, herpes zoster ophthalmia, panophthalmitis, rupture eye ball, penetrating injury, perforating injury, conjunctival cyst, Schiotz tonometre, field of vision test (confrontation).

$31-40 \%$ Dry eye syndrome, scleritis, complicated cataract, optic neuritis, papilloedema, optic atrophy, astigmatism, xanthelesma, ambyopia, trial box, retinal function test, tonometry (Schiotz)

21-30\% Secondary glaucoma, age related macular degeneration, lid with canaliculi injury, basal cell carcinoma.

11-20\% Cavernous sinus thrombosis, posterior uveitis, vitreous opacity, retinal artery occlusion, intra ocular foreign body, blow out fracture, meibomian gland carcinoma, paralytic squint, slit lamp, macular function test, retinoscopy, correction of refraction.

$1-10 \%$ Corneal dystrophy, retinal vein occlusion, central serus retinopathy, loupe.
Additional topics chosen by respondents were added in the topic list as below:

School sight test \& use of steroid, ocular therapeutic, laser treatment of eye, migrane, how to check V/A, primary eye care, \& referral system, anti glaucoma drugs, ophthalmia neonatorum, visual pathway, pupillary pathway, awareness about Vision 2020, use of ophthalmoscope to detect AMRD, and diabetic retinopathy, color vision test, etiology of red eye, eye irrigation, sinusitis, phaco surgery, eye hygiene, low vision, headache, enucleation, evisceration, lasik, keratoplsty. how to examin an eye and painful red eye.

\section{Result and analysis of round-2.}

The second questionnaire in this round was:

"How much a MBBS student should acquire percentage of knowledge, attitude and skill on each topic while being taught?"

A rearranged list of topics according to priority followed this question. Respondents had the opportunity for allocating the proportion (out of 100) of knowledge, attitude and skill the student should acquire. Appropriate boxes were given against each topic to provide their choice. Respondents' opinions were calculated in terms of mean.

Table-IV: Respondents' opinion calculated in terms of mean, an example:

\begin{tabular}{lccc}
\hline $\begin{array}{c}\text { Topic } \\
\text { concentrate } \\
\text { Lids }\end{array}$ & $\begin{array}{c}\text { Mean of knowledge } \\
\text { \% Allocated } \\
\text { proportion }\end{array}$ & $\begin{array}{c}\text { Mean of attitude } \\
\text { \% allocated } \\
\text { proportion }\end{array}$ & $\begin{array}{c}\text { Mean of skill } \\
\text { \% allocated } \\
\text { proportion }\end{array}$ \\
\hline Stye & 52 & 17 & 31 \\
Chalazion & 51 & 26 & 23 \\
Blepharitis & 48 & 22 & 30 \\
Trichiasis & 46 & 36 & 18 \\
Ptosis & 45 & 47 & 8 \\
Ectropion & 47 & 46 & 7 \\
Entropion & 49 & 43 & 8 \\
\hline
\end{tabular}

All the respondents expressed their strong opinion putting his highest marks in favor of knowledge component of learning domain in each topic with much emphasis on attitude component. But so far the skill component is concerned it varied topics wise.

On the basis of the opinion expressed by the respondents in favour of skill component of learning domains for each topic are rearranged in order of priority. 
Tabl-V: Skill components of each topics of round II rearranged in order of priority

[For example, orbital cellulites. weightage 100, knowledge component is $48 \%$ and attitude- $35 \%$, skill is $100-(48+35)=17 \%$ ]

\begin{tabular}{|c|c|}
\hline $\begin{array}{c}\text { Percentage } \\
\text { of Marks }\end{array}$ & Topics \\
\hline $31-35 \%$ & $\begin{array}{l}\text { Stye, bacterial conjunctivitis, allergic conjunctivitis, } \\
\text { acute dacryocystitis, xerophthalmia, school sight } \\
\text { test, primary eye care, day to day eye care, torch, } \\
\text { snellens visual acuity chart, near vision testing chart, } \\
\text { irrigation of eye. }\end{array}$ \\
\hline $26-30 \%$ & $\begin{array}{l}\text { Blepaharitis, viral conjunctivitis, ophthalmia } \\
\text { neonatorum, corneal abassion, chemical injury, } \\
\text { conjunctival injury, loupe, visual acuity test, eye } \\
\text { exam anterior segment, field of vision test } \\
\text { (confrontation). }\end{array}$ \\
\hline $21-25 \%$ & $\begin{array}{l}\text { Chalazion, keratomalacia, corneal foreign body, sub } \\
\text { tarsal foreign body, referral guide line, Vision-2020, } \\
\text { conjunctival F.B removal, migrane, headache, ocular } \\
\text { therapeutics, red eye DD. }\end{array}$ \\
\hline $16-20 \%$ & $\begin{array}{l}\text { Orbital cellulitis, trichiasis, trachoma, sac abacess, } \\
\text { chronic dacryocystitis, bacterial corneal ulcer, } \\
\text { presbiopia, lid injury, corneal injury, thermal burn, } \\
\text { retinoscope, colour vision test, retinoscopy, } \\
\text { correction of retraction. }\end{array}$ \\
\hline $11-15 \%$ & $\begin{array}{l}\text { Ptrygium, congenital NLD obstruction, dry eye } \\
\text { syndrome, penetrating lnjury, lid with canaliculi } \\
\text { injury, low vision, corneal fb-removal, chalazion, } \\
\text { puprillary path way, cn palsy- iii, vi, vi \& vii, slit } \\
\text { lamp- eye exam, posterior segment. }\end{array}$ \\
\hline $06-10 \%$ & $\begin{array}{l}\text { Propotosis, thyroid ophthalmopathy, cavernous sinus } \\
\text { thrombosis, ptosis, ectropion, entropion,corneal } \\
\text { dystrophy, poserior uveitis, congenital cataract, } \\
\text { complicated cataract, congenital glaucoma, vitreous } \\
\text { opacities, diabetic retinopathy, hypertensive } \\
\text { retinopathy, retinal artery occlusion, age related } \\
\text { macular degeneration, retinal vein occlusion, central } \\
\text { serous retinopathy, optic atrophy, papilloedema, } \\
\text { optic neuritis, astigmatism, rupture eye ball, blowout } \\
\text { fracture, intra ocular foreign body, leucocoria in } \\
\text { children, retinoblastoma, dermoid, conjunctival cyst, } \\
\text { xanthelesma, haemangeoma, squint, ambyopia, } \\
\text { nystigmus, paralytic squint, the national eye care } \\
\text { plan of bangladesh, ptrygium, corneal ulcer- } \\
\text { tarsorraphy, lacrimal sac, cataract, glaucoma, visual } \\
\text { pathway, flu angeography. }\end{array}$ \\
\hline $01-05 \%$ & $\begin{array}{l}\text { Squamous cell carcinoma, corneal ulcer, conjuntival, } \\
\text { hood, refractive surgery, laser treatment. }\end{array}$ \\
\hline
\end{tabular}

Result \& Analysis of Workshop

All the findings of round-I and II along with topics added by the respondents were presented to a workshop attended by 24 expert ophthalmologist for discussion, criticism, opinion, addition, changes or modifications if any and finally for validation. Opinion, comments and suggestion of the body of the expert ophthalmologists are summarized as: (a) This research on ophthalmology curriculum is first such in Bangladesh. This presentation opened a new door for future study. (b) Suggested to add some topics in the ophthalmology curriculum: magnitude of blindness, epidemiology of common eye diseases, low vision and rehabilitation, health education (eye related), topics related to development of attitude, towards welfare of the patients, community eye organization and outreach activities. (c) Suggested to give emphasis on the topic "practice of refraction" for hands on training of under graduate medical students. So that they can prescribe glass in a rural setup. (d) Finally the "Body of Expert Ophthalmologists" accepted this study as reference for future modification of present ophthalmology curriculum for under graduate medical course in Bangladesh.

\section{Discussion}

In 1999 and 2000 The International Council of Ophthalmology $(\mathrm{ICO})^{2}$ and the Academia Ophthalmologic Internationalis developed an international strategic plan to preserve and restore vision: "vision for the future". This strategic plan involved multipronged approach to reduce visual impairment and blindness worldwide. As part of this strategic plan four international task forces were established one for to develop curriculum for training of medical students.

The taskforce while developing a curriculum on ophthalmology for medical students noted that:

1. In the $21^{\text {st }}$ century eye care has become increasing important in the general practice of medicine.

2. Vision is one of the vital factors influencing quality of life.

3. Ophthalmic manifestations of systemic diseases are common,

4. A solid education in ophthalmology should be a part of the comprehensive education of modern physician.

5. Historically, teaching methods of ophthalmology for medical students are traditional as for other subjects. Patients contact and bedside teaching in ophthalmology are critical in providing clinical experience on it.

6. Ophthalmology is mostly a surgical speciality \& medical students should have enough exposure.

7. The time allotment for teaching students in ophthalmology is important.

Doctors should be aware of the community health need and their knowledge, attitude and skill should be shaped appropriately to address all those problems. Like other priority health problems, eye diseases are getting the attention of the health care provider due to its magnitude and undesirable outcome on the quality of life. But it is also hopeful that many of the eye diseases and its sequel are preventable. Many world health forum have taken eye care as one of the primary component of basic health care. These professionals are giving stress to 
general doctors as well as ophthalmologists capable enough to provide those primary eye care.

Doctor should be prepared in such a way that he will not play only the role of curer but also organizer for the community to lead forward for making a healthy community which Dr. Charles Boelen ${ }^{\mathbf{1 6}}$ mentioned in his word as a "Five Star Doctor", a doctor possessing a mix of aptitudes to carry out the range of services that health settings must deliver to meet the requirements of relevance, quality, costeffectiveness and equity in health. The five sets of attributes of the "Five Star Doctor" are: care provider, decision-maker, communicator, community leader and manager. Medical schools have an important role to play to produce such doctors.

The $\mathrm{ICO}^{2}$ taskforce queried members of the International Federation of Ophthalmological Society and determined that all medical students should demonstrate competency in the following areas:- a) Measurement of distant and near visual acuity with and without correction. b) Determination of visual fields by confrontation technique. c) Assessment of extraocular motility in the six cardinal position of gaze and primary position. d) Measurement and interpretation of pupillary size and reaction to light. e) Penlight examination of the anterior segment including upper lid eversion. f) Examination of the optic nerve and posterior pole with direct ophthalmoloscope. g) Removal of superficial corneal or conjunctival foreign body. Our research reflects the same opinion.

In addition ICO suggested the graduating medical student should be able to make the following diagnoses and initiate an appropriate treatment or referral plan for the following conditions: conjunctivitis, cataract, corneal ulcer, corneal and conjunctival foreign body, hypertensive retinopathy, glaucoma, uncorrected refractive error, ocular trauma, papilledema, hemianopic and bi-temporal visual field defects, acute onset of cranial nerve palsies III, IV, VI, VII, acute onset strabismus and leukocoria.

The current curriculum on ophthalmology for undergraduate medical course in Bangladesh is effective from $2002^{\mathbf{1 4}}$, which determines a list of content rather than a total community need based curriculum. The goal of the present curriculum is to make the students to be competent in taking appropriate history, carrying out examination of eye with the ability to diagnose and plan for the treatment of stye, chalazion, dacryocystitis, conjunctivites, corneal ulcer, iritis, glaucoma, cataract, retinoblastoma, ocular injury, vit-A deficiency (ocular manifestations), refractive errors and orbital diseases.
In round-I of the study respondents chosen all those topics areas as priority.

Table-VI: The topics/diseases given weightage from $100 \%$ to $50 \%$ in round-I are rearranged according to priority under each topic concentrate heading.

\begin{tabular}{ll}
\hline Group & \multicolumn{1}{c}{ Topics } \\
\hline Orbit: & $\begin{array}{l}\text { Orbital cellulitis } \\
\text { Lids: }\end{array}$ \\
Stye, chalazion, blepharitis, trichiasis, ectropion, \\
ptosis. \\
Viral conjunctivities, allergic conjunctivitis, \\
bacterial conjunctivitis, vernal conjunctivitis, \\
ptrygium.
\end{tabular}

Pattern and prevalence of eye diseases differs time to time in geo-graphic region, country to countries and place to place inside a country. So it needs continuous modifications of curricula according the needs of different global community.

While evaluating the community need for ophthalmology care we visited many studies. Only two studies showed an elaborated list of diseases that mostly occurred in Bangladesh. A rural based study was done by $\mathrm{Khan}^{17}$ reveals: refractive error top the list with $28 \%$ alone of all diseases followed by diseases of cornea $15.79 \%$, then conjunctiva \& sclera $13.46 \%$, lens- $13.17 \%$, lacrimal apparatus$6.11 \%$, ocular Injury-5.88\%, diseases of retina $2.02 \%$, that of lids-1.79\%, uvea- $1.12 \%$, neurophthalmology related diseases $0.67 \%$, tumor$0.41 \%$, vit-A deficiency- $0.36 \%$, diseases of vitroretina- $0.24 \%$, congenital (other than cataract) $0.14 \%$ and squint- $0.10 \%$.

The study was conducted on randomly selected 8409 (even numbered out of total 16,818) new eye patients attended at out patients department (OPD) of Dristisheba O Gobeshona (private eye care centre), Jamalpur during 2003-2005. Main features are as follows: 
Table-VII: Main features of ocular disease pattern in rural Bangladesh

Refractive error-Total-2379 (28.29\%), presbiopia-1431, myopia1000, pseudophakia-112, aphakia-57, hypermetropia-34.

Cornea

Total $1328(15.79 \%)$ highest viral keritities-861, corneal ulcer- 342, corneal opacity-43, dentritic ulcer- 41, marginal ulcer-19, herpes zoster ophth19. lowest karatokonas-2, and corneal dystrophy-1.

Conjunctiva \&: Total - 1132, (13.46\%) Alergic, conjunctivitis-575, Sclera Ptrygium-164, virial and bacterial conjungtivities128, episclitis-105, vernal conjunctivitis-91, subconjunctival hemorrhage-54, scleritis-2, pinguicola-19, ophthalmia neonatorum-7, sub tarsal concretion-5, sclerities- 2 .

Lens : Total-1108 (13.17\%) mature cataract-398, advance cataract-322, immature cataract-271, hyper mature cataract-65, congenital cataract-24, complicated cataract-13, developmental cataract-6, lens dislocation-5, sub luxeted lens-3.

Miscelleneous: Total-704(8.34\%), eye pain-121, headech-120, migraine-59, vertigo-45, atropine mydriasis-34, amblyopia-16, ndophtalmities-13, proptosis-9, pthysis bulbi-8. orbital cellulities-3, malingering-2 .

Lacrimal : Total-652(7.75\%), chronic DC-197, watering-129,

apparatus NLD obst-120, sac abscess-100, dry eye syndrom-6.

Injury : Total-495 $(5.88 \%)$, conjunctival injury-143, corneal FB-103, lid-51, cornea-53, penitrating-43, ruphture5 traumatic hyphema-5, optic nerve avulsion-1, intraocular FB-1, lime burn-1.

Retina : Total-170(2.02\%), csr-45, retinities pigmentosa-20, optic atrophy-17, crvo-8, crao-4, macular hole-9, brvo-upper temporal-11, lower temporal -5, RD-2. hypertensive retinopathy-1, papilodema-1, retinal hemorrhage-4, diabetic retinopathy-14, diabetic papillopathy-2, retinopathy-4, maculopathy \& ARMD-23.

Glaucoma : Total-173 (2.02\%), absolute glaucoma-62, poag-32, lens induced glaucoma-32, acute congestive glaucoma-22. secondary glaucoma-13, chronic congestive glaucoma-9, congenital glaucoma-3.

Lids : Total-151 (1.79\%) blepharities-44, chalazion-44, mebomitis-34, trichiasis-6, trachoma-2.entropion-1, ectropion-4, ptosis-4, stye-2, ange neurotic oedema 1.

Uvea : Total-98 $(1.12 \%)$ acute irities 68 , posterior uveitis11, choiditis-7, chronic iritis-6, phacolytic uvities-3. phacolytic ueitis-3.

Neuro Ophth : Total 58(6.67\%), retrobulbar optic neurities -16, bell's-8, optic atrophy-8, cranial nerve palsy-iiiwith pupil-7, without pupil-4, iv-3, vi-3, trigeminal ophthalmoplegia-2, neuralgia-1, adde's pupil-1. cerebral palsy-1, papillitis-1, Down's syndrome-1.

Tumours : Total-36 $(0.41 \%)$, conjunctival cyst-16, nevi-6, basal cell carcinoma-5 dermoid-5, conjunctival papilloma-2. retino-blastoma-1,

Vit-A-deficiency:Total-31 (0.36\%). keratomalacia-10, Bittot"s spot8 , night blindness-8, xerophthalmia-5,

Vitreous : Total $-21(0.24 \%)$ opacity- 19 , haemorrahge-2.

Congenital : Total $-13(0.14 \%)$, congenetal squint-6, glaucoma3, microphthalmia-2.coloboma iris-2,

Squint : Total-9 $(0.10 \%)$

NAD : Total-194(2.3\%)

Similar ocular disease pattern had been identified by S. Ahmed et $\mathrm{al}^{\mathbf{1 8}}$ in 2005 . Which was an urban bound based study and conducted at OPD of Bangabandhu Sheikh Mujib Medical University (BSMMU) at Dhaka, a tertiary multidisciplinary hospital.
Table-VIII: A comparative analyses of ocular disease pattern of urban and rural hospital of Bangladesh

\begin{tabular}{lcc}
\hline \multicolumn{1}{c}{ Diseases } & Ahmed $^{\mathbf{1 8}}$ & Khan $^{\mathbf{1 7}}$ \\
\hline Refractive error & $35.66 \%$ & $28.29 \%$ \\
Conjunctival disease & $21.41 \%$ & $13.46 \%$ \\
Cataract & $10.30 \%$ & $13.17 \%$ \\
Lacrimal disease & $08.13 \%$ & $04.93 \%$ \\
Corneal ulcer (all) & $02.50 \%$ & $04.30 \%$ \\
Viral Keratities & $01.5 \%$ & $10.72 \%$ \\
Glaucoma (all) & $01.02 \%$ & $02.21 \%$ \\
Retinal disease (all) & $01.58 \%$ & $02.21 \%$ \\
Uveal disease & $00.98 \%$ & $01.22 \%$ \\
Migrain & $02.04 \%$ & $00.70 \%$ \\
\hline
\end{tabular}

The ocular disease pattern in Bangladesh was a top concern while developing this curriculum.

The priority topics chosen for skill development by the respondents in round II given below is very much consistent with ocular disease pattern in Bangladesh.

Table-IX: Topics/diseases weightage given between $35 \%$ to $16 \%$ for skill areas in round II are rearranged according to priority under each topic concentrate heading.

\begin{tabular}{|c|c|}
\hline Group & Topics \\
\hline Orbit: & Orbital cellulitis \\
\hline Lids: & $\begin{array}{l}\text { Stye, chalazion, blepharitis, trichiasis, ectropion, } \\
\text { ptosis. }\end{array}$ \\
\hline Conjunctiva: & $\begin{array}{l}\text { Bacterial conjunctivitis, viral conjunctivitis, } \\
\text { ophthalmia neonatorum, trachoma. }\end{array}$ \\
\hline Cornea: & Bacterial corneal ulcer. \\
\hline $\begin{array}{l}\text { Lacrimal } \\
\text { apparatus }\end{array}$ & $\begin{array}{l}\text { Acute dacryo cystitis, chronic dacryocystitis, sac } \\
\text { abscess. }\end{array}$ \\
\hline Vita \& Eye: & Xerophthalmia, keratomalasia. \\
\hline $\begin{array}{l}\text { Community } \\
\text { ophthalmology: }\end{array}$ & $\begin{array}{l}\text { School sight test, primary eye care, day to day eye } \\
\text { care, referral guideline, vision- } 2020 \text {. }\end{array}$ \\
\hline Eye Injury: & $\begin{array}{l}\text { Corneal abression, chemical injury, conjunctiva } \\
\text { injury, corneal foreign body, sub tarsal foreign } \\
\text { body, lid injury, corneal injury, thermal burn. }\end{array}$ \\
\hline $\begin{array}{l}\text { Technical know } \\
\text { how }\end{array}$ & $\begin{array}{l}\text { Torch, smellers visual acuity chart, near vision } \\
\text { testing chart, retinoscope. }\end{array}$ \\
\hline $\begin{array}{l}\text { To pertorm } \\
\text { (skill of) }\end{array}$ & $\begin{array}{l}\text { Irrigation of eye, V.A test, eye examination } \\
\text { anterior segment, field of vision test } \\
\text { (confrontation ophthalmoscopy, macular vision } \\
\text { test, retinoscopy, correction of refraction. }\end{array}$ \\
\hline Operation for & Conjunctiva foreign body removal. \\
\hline Miscellaneous & Migraine, headech, ocular therapentics. \\
\hline
\end{tabular}

Though refractive error, retinoscopy and correction of refraction scored $20 \%$ in topic choice component in round-I and scored 18\%, $17 \%$ \& $20 \%$ respectively in skill component in round-II, although refractive error occupies the top of ocular diseases profile in patients attending in hospitals, both urban, suburban \& rural eye centers, practice of refraction to develop skill for correction of refraction is not included in the current curriculum. But respondents opined in favor of it.

In the existing undergraduate ophthalmology curriculum, topics included from topic concentrate community ophthalmology is school sight testing program. A good number of topics other than above one were proposed by respondents in Round-I Delphi to include in curriculum. Those are primary eye care, day to day eye care, vision-2020, The National Eye Care Plan of Bangladesh, magnitude of blindness, epidemiology of common eye diseases, strategies for prevention of blindness, community 
eye organization and eye health education. All these topics were chosen to add in Round-II Delphi by the respondents. In the study report by WHO in SEAR countries these topic are mentioned and urged to include with importance in curriculum.

In regard to the training hours for the under graduate medical course the task force of ICO strongly recommends that all medical schools include ophthalmology as a part of the essential curriculum and not exclusively as an elective. The task force estimates that the total educational commitment throughout medical school will require approximately 40-60 hours exposure. The same committee also recommended three teaching methods to achieve educational goal: didactic lectures, clinical demonstration: illustrative case method study and evidence based medical teaching to fulfill the learning.

In the present curriculum teaching methods and allocated teaching hours suggested is very much consistent with suggestion of ICO and is as follows: Lecture, tutorial (clinical demonstration), demonstration (in OT), case presentation, video, school sight testing

Table-X:Teaching hours allocated for ophthalmology:

\begin{tabular}{cccc}
\hline & $4^{\text {th }}$ year & $5^{\text {th }}$ year & total \\
\hline Lecture & $\mathrm{X}$ & 40 hours & 40 hours \\
Word \& OPD & 2 weeks & 4 weeks ward & 8 weeks \\
& OPD & and 2 weeks OPD & \\
\hline
\end{tabular}

But study reveals that in SEAR countries ${ }^{\mathbf{1 0}} 48.74 \%$ of medical college has less than 30 lectures scheduled for ophthalmology, set with higher hours including Bangladesh. In $66 \%$ of medical colleges duration of OPD posting was less than 30 days. Similarly in eye words $58 \%$ with less than 30 days posting, exception in India with longer duration. In $68 \%$ of colleges a separate examination in ophthalmology was conducted as like ours though as part of Surgery. Over $95 \%$ of the colleges reported conducting some form of internal assessment during undergraduate medical education. Forty three percent institutions had no specific hours allocated for community ophthalmology training, only in few institution (mostly in India) were more than 10 hours devoted to community ophthalmology teaching. Over all more than $80 \%$ stated that community ophthalmology training in the region was inadequate. In our present curriculum there is no designated hours for community ophthalmology but respondents opined in favor. Respondents also opined to incorporate the learning domain attitude for each topic of the curriculum.

Conclusion: Finally on the basis of the opinion of the respondents, reviewing literature, analyzing the ocular disease pattern in Bangladesh and also analyzing the present ophthalmology curriculum, a community and need based ophthalmology curriculum for undergraduate medical course in Bangladesh was developed. This research would help developing community and need based ophthalmology curriculum for undergraduate medical course in Bangladesh.

\section{References}

1. Prideaux D. ABC of Learning and teaching in Medicine, curriculum design. BMJ 2003; 326:268-70.

2. International council of Opthalmology Klinische Monatsblatter fur Augenheilkunde. November 2006.

3. Hussain AZMI. Project report: Development of curriculum for the course of MPH in Community Ophthalmology of a selected University for capacity building of the health professionals to reduce the burden from eye health problem in Bangladesh. London School of Hygiene \& Tropical Medicine. London, 2006.

4. WHO Conference on: Priorities at the interface of health care, medical practice and medical education: report of the global conference on international collaboration on medical education and practice, Rockford, Illinois, USA, 12-15 June 1994.

5. Harden RM. Ten question to ask when planning a course or curriculum. Centre for Medical education. Dundee, UK.

6. Bligh $\mathrm{J}$ et al. New educational strategies for medical education. Med Educ 2001; 35: 520-521.

7. World Bank. World development indicators: Bangladesh. E. Source 2011.

8. National Eye Care Plan for Bangladesh 2005.

9. Kalam APJA. "Removal of avoidable blindness, our mission". Indian Journal of ophthalmology 2007; 55(2): 91-93.

10. Bangladesh National Blindness and Low Vision Survey, Summery Report 2003.

11. Worth S, Mashitiw. "How effective is undergraduate and postgraduate teaching in Ophthalmology"? Eye 1997; 11: 744-50.

12. WHO: Study on status of ophthalmic medical education in South East Asia Region- An overview". Project No IPC DPR 001.WHO, New Delhi, April 2002.

13. Jacobs DS. "Teaching doctors about the eye: tendons in the education of Medical students". Surv Ophthalmol 1998; 42: 383-89.

14. Curriculum for undergraduate medical education in Bangladesh 2002. Compiled and edited by Center for Medical Education (CME), IPH Building, Mohakhali, Dhaka.

15. Dalkey, NC, \& Helmer, O. An experimental application of the Delphi method to the use of experts. Management Science 1963; 9(3): 458-67.

16. Boelen. The Five-Star Doctor: An asset to health care reform. World Health Organization, Geneva, Switzerland.

17. Khan AK. Ocular disease pattern in rural Bangladesh. Journal of Ophthalmological Society of Bangladesh 2006; 33(2): 68-73.

18. Ahmed S. Ocular Disease pattern, Book of abstract, Ophthalmological Society of Bangladesh. Annual Conference 2003. 